Dicle Tip Dergisi / Dicle Med J (2018) 45 (3) : 283-290

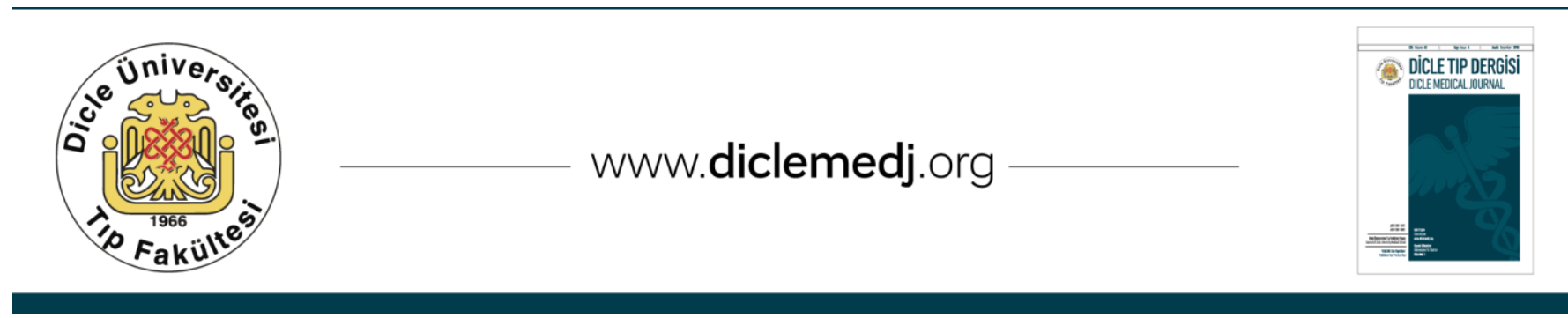

Özgün Araștırma / Original Article

\title{
Adölesan Gebelerin Maternal ve Fetal Sonuçlarının Değerlendirilmesi
}

\author{
Mert Ulaş Barut1 \\ 1 Harran Üniversitesi Tıp Fakültesi Kadın Hastalıkları ve Doğum AD, Șanlıurfa, Türkiye ORID: 0000-0002-7008-8218 \\ Geliş: 05.02.2018, Revizyon: 21.05.2018, Kabul Tarihi: 24.05.2018
}

Öz

Amaç: Çalışmamızda adölesan gebelerin maternal ve fetal sonuçlarını karşılaştırmayı amaçladık.

Yöntemler: Bu çalışmada, Ocak 2017-Ocak 2018 tarihleri arasında doğum yapmıș, 15-19 yaş aralığında 68 adölesan gebe ve kontrol grubu 20-23 yaş aralığında 168 gebe retrospektif olarak değerlendirildi. Toplam 236 gebenin kayıtları incelendi. Mevcut kayıtlarda gebelerin demografik özellikleri, doğum şekli ve fetal sonuçları rapor incelendi. Adölesan gebeler ile kontrol grubu gebelerin maternal ve fetal sonuçları karşılaştırıldı.

Bulgular: Ocak 2017-Ocak 2018 tarihleri arasında toplam doğum sayısı 1601 olarak tespit edildi. Bunların 68'inin $(\% 4,2)$ 15-19 yaş adölesan gebe grubunda iken, 168'i $(\% 10,4)$ 20-23 yaş adölesan olmayan gebe grubunda olduğu tespit edildi. Adölesan gebelerin 16'sının $(\% 23,5)$ kan transfüzyonu yapılırken, kontrol grubundakilerin 4'üne $(\% 2,4)$ kan transfüzyonu yapıldığı saptandı ve iki grup arasında istatistiksel olarak anlamlı fark bulundu $(\mathrm{P}=0.00)$. Çalışma grubunda 9 hasta $(\% 13,2)$ yoğun bakıma alınırken, kontrol grubunda ise 2 hasta $(\% 1,2)$ yoğun bakıma alındığı ve iki grup arasında istatistiksel olarak anlamlı fark saptandı $(\mathrm{P}=0.00)$. İki grup sezaryene endikasyonları açısından karşılaştırıldığında; adölesan gebelerin \%10,3'ünün plasenta previa, \%8,8'inde mükerrer sezaryen saptanırken, adölesan olmayan grupta \%3'ünün plasenta previa, \%31,5'inde mükerrer sezaryen bulundu (P değerleri sirasıyla; $\mathrm{P}=0.020, \mathrm{P}=0.000)$. Çalışma grubunda $26(\% 38,2)$ preterm doğum eylemi tespit edilirken kontrol grubunda ise 15 $(\% 8,9)$ hastada preterm doğum eylemi tespit edildi $(\mathrm{P}=0.00)$.

Sonuç: Adölesan gebelerde maternal kan transfüzyonu, yoğun bakım ihtiyacı ve preterm eylem sıklığı daha yüksek bulunduğundan, adölesan gebelerin yüksek riskli gebelikler olarak değerlendirilmelidir. Dolayısıyla adölesan gebeliklerin antenatal ve peripartum takipleri yüksek riskli gebelikler kategorisinde olması, istenmeyen sonuçlarını azaltabilir .

Anahtar Kelimeler: Adolesan gebelik, preterm dogum, maternal sonuçlar.

DOI: 10.5798/dicletip.457244

Yazışma Adresi / Correspondence: Mert Ulaş Barut, Harran Üniversitesi Tıp Fakültesi Kadın Hastalıkları ve Doğum AD, Şanlıurfa, Türkiye, e-mail: drmertulas@gmail.com 


\title{
An Analysis of Maternal and Foetal Outcomes of Adolescent Pregnancies
}

\begin{abstract}
Objective: In our study, we aim to compare maternal and foetal outcomes of adolescent pregnancy.

Methods: In this study, 68 pregnant adolescents, who are between 15-19 years old and have given a birth in January 2017- January 2018, have been retrospectively examined. Moreover, 168 non-adolescent pregnant women, aged between 20-23, are determined to be the control group. The results of a total of 236 patients were analysed. Such parameters as demographical features of the mother, delivery method and foetal outcomes of pregnant adolescents were recorded. Maternal and foetal outcomes of pregnant adolescents and non-adolescent pregnant women (control group) were compared.
\end{abstract}

Results: The number of births is recorded to be 1601 in the period between January 2017- January 2018. Of these 1601 births, 68 (4.2\%) were adolescents aged between 15-19. On the other hand, 168 women (10.4\%) were nonadolescent, aged between 20-23. 16 of adolescent pregnants $(23.5 \%)$ received blood transfusion while only $4(2.4 \%)$ women in the control group got blood transfusion. A statistically meaningful difference was determin ed between the two groups $(\mathrm{P}=0.00)$. In research group, 9 patients $(13.2 \%)$ were put into intensive care unit whereas two patients $(1.2 \%)$ in the control group needed intensive care. Therefore, we observed statistically meaningful difference between the two groups $(\mathrm{P}=0.00)$. When the two groups were compared in terms of caesarean indications, $10.3 \%$ of adolescent women were reported to have placenta previa, and $31.5 \%$ of them were determined to have repetitive caesarean. (P values are $\mathrm{P}=0.020, \mathrm{P}=0.000$ respectively). In the research group, 26 cases $(38.2 \%)$ of preterm birth were identified while, in the control group, the number of preterm birth case was $15(8.9 \%)(\mathrm{P}=0.00)$.

Conclusion: Since adolescent pregnancy has a more frequent incidence of maternal blood transfusion, intensive care need, and preterm birth risk, it should be considered to be risky pregnancies. Therefore, their antenatal ve peripartum monitoring should be conducted carefully so that hazardous outcomes could be eliminated.

Keywords: Adolescent pregnancy, preterm birth, maternal outcomes.

\section{GíRIŞ}

Adölesan dönemi hem psikololojik hem de sosyal değişim sürecinde çocukluktan erişkinliğe geçiş dönemini olarak tanımlamaktadır. Dünya Sağlık Örgütü (WHO) verilerinde adölesan dönem, 10-19 yaş arası olarak tanımlanmakta iken, erken adölesan yaş 10-14, geç adölesan yaş ise 15-19 olarak tanımlanmıştır ${ }^{1}$. Adölesan gebelikler, gelişmemiş ülkelerin bir sorunu olmasına rağmen, aynı zamanda gelişmiş ülkelerin de karşılaştığı bir sorun olarak görülmektedir. Gelişmiş ülkelerdeki adölesan gebeliklerin büyük çoğunluğu istenmeyen ve evlilik dışı adölesan gebeliklerdir ${ }^{2}$. Adölesan gebeliklerin sıklığı ülkenin gelişmişlik düzeyi ve sosyokültürel durumu gibi birçok faktörden etkilenebilir. Türkiye'deki araştırmalara baktığımızda toplam nüfusun \%21,6'sı adölesan olup, gebelerin \%8-12'si adölesan döneminde vuku bulmaktadır. Adölesan gebeliklere, Türkiye'nin doğu ve güneydoğu bölgelerinde daha sık rastlanmaktadır ${ }^{3}$. Adölesan gebelikler, diğer adölesan olmayan gebeliklerle kıyaslandığında daha riskli grup olarak kabul edilmişlerdir. Yapılan bir çalışmada, 18 yaş altında adölesanların okulu terk etmesinden dolayı eğitim seviyesinde düşme, adölesan gebelik oranında artma, anne ve bebeğin mortalite ve morbiditesinde artış ve yoksulluk gibi çeşitli istenmeyen sonuçlara yol açtığı rapor edilmiştir4. Ayrıca adölesan annelerden doğan bebekler yeni doğan ölümü ve hastalıkları açısından risk taşıdığı gibi, adölesan annelerde doğum öncesi bakımları yetersiz olduğundan obstetrik komplikasyonlar ile daha sık karşılaşılmaktadır ${ }^{5}$.

Dünyada adölesan gebelik oranı \%5,4 olup, WHO verilerine göre, dünyada her yll yaklaşık 70.000 adölesan gebe, gebelik ve doğuma bağlı komplikasyonlar nedeniyle ölmektedir 6 . 
Adölesan yaş gebelikleri önemli bir halk sağlığı problemi olarak ortaya çıkmaktadır ve dünyadaki tüm gebeliklerin \%11'ini oluşturmaktadır. Bunların da çoğu düşük gelirli ülkelerde vuku bulmaktadır. Adölesan gebelikler, gelişmekte olan ülkelerde baskı altında evlenme nedeniyle ortaya çıkarken, gelişmiş ülkelerde adölesan yaş gebelikleri ise gebeliğe karşı yetersiz korunma yöntemleri nedeniyle oluşmaktadır. Planlanmamış bir ergen hamileliği, özellikle genç ergenlikte ciddi fiziksel, psikolojik ve sosyal sonuçlar doğurabilir7 ${ }^{7}$ Adölesan gebelerin büyümelerini tamamlanmadığı için rezervleri çok düşüktür. Bundan dolayı fetal büyüme ve emzirme, ergenlerin beslenme ihtiyaçlarını arttırır. Adölesan gebelikle ilgili riskler anneye ve yeni doğana taşınır. Major gebelik komplikasyonları; şiddetli anemi, böbrek komplikasyonları, eklampsi, preeklamsi ve doğum sirasındaki komplikasyonlarıdır (örneğin vesiko-vajinal veya rekto-vajinal fistüller). Adölesan gebeliğin psikolojik ve sosyal sonuçları, ailenin ve toplumun kabulüne bağlıdır. Birçok kültürde, hamile kalan ergen, utanç duygusu ve suçluluk duygusu taşır, ve anlayış eksikliği ve reddetme korkusu nedeniyle durumu mümkün olduğu kadar ailesi ve toplumdan gizler. Pek çok ülkede, gebe bir ergen okulu birakmak zorunda kalır.

Tüm bu veriler ışığında çalışmamızda, 20172018 yılları arasında doğum yapan 15-19 yaş adölesan gebeliklerin obstetrik ve neonatal sonuçlarını tespit edip, sonuçları, adölesan olmayan 20-23 yaş arası kontrol grubu ile karşılaştırmayı amaçladık.

\section{YÖNTEMLER}

Tersiyer bir merkezde Kadın Hastalıkları ve Doğum Kliniğinde Ocak 2017 ile Ocak 2018 tarihleri arasında doğum yapmış 15-19 yaş aralığında 68 Adölesan gebe ve kontrol grubu olarak 20-23 yaş aralığında 168 doğum yapmış gebeleri retrospektif olarak değerlendirildi. Çalışmamızda artan parite ve yaşın, fetal ve maternal sonuçlara olumsuz etkisini azaltabilmek için 20-23 yaş aralığı kontrol grubu olarak seçildi. Toplam 236 hastanın kayıtları incelendi. Bunların 68'inin (\%4,2) 1519 yaş adölesan gebe grubunda iken, 168'i $(\% 10,4)$ 20-23 yaş adölesan olmayan gebe grubunda olduğu izlendi. Mevcut kayıtlardan anne ile ilgili demografik özellikler, doğum esnasındaki yaş, daha önceki gebelik öyküsü (gravide, parite), nabız, tansiyon, kilo, boy, öyküsünde sigara içip içmediği, gebelik haftası, preterm eylem, hastaların doğum şekli, doğumda oluşan komplikasyonlar (omuz takılması, hastaların perine laserasyonları, kanama), sezaryen endikasyonları, gebelerin hematokrit (HTC), hemoglobin (HB), platelet (PLT), glukoz, aspartat transaminaz (AST), alanin transaminaz (ALT), idrarda protein miktarı, preeklampsi olup olmadığı ve eklampsi ile ilgili sonuçları kayıt edildi. Maternal kan transfüzyonu, maternal yoğun bakım ihtiyacl, maternal ölüm olup olmadığı da araştırıldı. Doğum şekli ve fetal sonuçlar (doğumdan sonra bebeğin 1. ve 5 . dakika APGAR skoru, bebeğin doğum ağırlığı, bebeğin amnion mayisinde mekonyum olup olmadığı, fetal anomali olup olmadığ $)$ analiz edildi. Veriler hastane arşiv taraması yapılarak kayıt edildi.

Çalışmamız Üniversite Etik Kurulu tarafından gerekli etik kurulu onayı alınmıştır.

İstatistiksel değerlendirme: verilerin analizinde SPSS 20,0 paket programı kullanıldı. Toplanan verilerin aritmetik ortalaması ve standart sapma değerleri hesaplandı. Normal dağılım verilerini değerlendirmek için KolmogorowSmirnow testi kullanıldı. Dağılımı normal olmayan veriler için nonparametrik testlerden Mann Whitney U testi uygulandı. Normal dağılım gösteren parametrik değerler için Student T testi kullanıldı. Verilen \% değerlerin karşılaştırılmasında deskriptif istatistik yöntemi kullanıldı. Kategorik değişkenler için ise Ki-kare testi $(\chi 2)$ kullanılmıştır. $p<0,05$ anlamlı olarak kabul edilmiștir. 
Tablo 1: Adölesan gebeler ile kontrol grubu gebelerin demografik parametrelerinin karşılaștırılması

\begin{tabular}{|c|c|c|c|c|}
\hline & & \begin{tabular}{|l|} 
Adölesan \\
gebeler \\
mean \pm SD (min- \\
max), n(\%)
\end{tabular} & $\begin{array}{l}\text { Kontrol grubu gebeler } \\
\text { mean } \pm \text { SD }(\min -m a x) \\
\text { n(\%) }\end{array}$ & $\mathbf{P}$ \\
\hline Yaş( yll) & & $\begin{array}{l}18.18 \pm 0.98 \\
(15.00-19.00)\end{array}$ & $\begin{array}{l}21.67 \pm 1.10 \\
(20.00-23.00)\end{array}$ & 0.000* \\
\hline Kilo(kg) & & $\begin{array}{l}67.38 \pm 4.82 \\
(56.00-80.00)\end{array}$ & $\begin{array}{l}70.43 \pm 4.10 \\
(59.00-80.00)\end{array}$ & $0.000 *$ \\
\hline Boy $(\mathrm{cm}$ & & $\begin{array}{l}1.69 \pm 0.05 \\
(1.54-1.76)\end{array}$ & $\begin{array}{l}1.68 \pm 0.06 \\
(1.54-1.78)\end{array}$ & 0.275 \\
\hline Doğum & Primipar & $46(\% 67.6)$ & $93(\% 55.4)$ & \\
\hline sayls & Multipar & $22(32.4)$ & $75(\% 44.6)$ & 0.002 \\
\hline Gebelik & sayısı & $\begin{array}{l}1.69 \pm 1.00 \\
(1.00-3.00) \\
\end{array}$ & $\begin{array}{l}2.20 \pm 1.31 \\
(1.00-6.00) \\
\end{array}$ & $0.004 *$ \\
\hline \begin{tabular}{|l}
$\begin{array}{l}\text { Yaşayan } \\
\text { sayısı }\end{array}$ \\
\end{tabular} & çocuk & $\begin{array}{l}0.63 \pm 0.86 \\
(0.00-3.00)\end{array}$ & $\begin{array}{l}0.96 \pm 1.01 \\
(0.00-5.00)\end{array}$ & $0.014 *$ \\
\hline Gebelik & haftası & $\begin{array}{l}34.46 \pm 4.09 \\
(19.00-39.00)\end{array}$ & $\begin{array}{l}36.47 \pm 2.93 \\
(23.20-40.60)\end{array}$ & $0.000^{*}$ \\
\hline & Yok & $58(\% 85,3)$ & $152(\% 90,5)$ & \\
\hline Jigdld & Var & $10(\% 14,7)$ & $16(\% 9,5)$ & 0.250 \\
\hline & $\begin{array}{l}\text { Normal } \\
\text { Doğum }\end{array}$ & $30(\% 44,1)$ & $58(\% 34,5)$ & \\
\hline $\begin{array}{l}\text { Doğum } \\
\text { șekli }\end{array}$ & \begin{tabular}{|l|} 
Operatif \\
Doğum
\end{tabular} & $3(\% 4,4)$ & $4(\% 2,4)$ & 0.227 \\
\hline & Sezaryen & $35(\% 51,5)$ & $106(\% 63,1)$ & \\
\hline \begin{tabular}{|l|} 
Sistolik \\
Basincl
\end{tabular} & $\begin{array}{l}\text { kan } \\
(\mathrm{mm} H g)\end{array}$ & $\begin{array}{l}118.37 \pm 13.76 \\
(90-160)\end{array}$ & $\begin{array}{l}120.77 \pm 16.05 \\
(95-130)\end{array}$ & 0.280 \\
\hline $\begin{array}{l}\text { Diastoli } \\
\text { Basincl }\end{array}$ & $\begin{array}{l}\text { k Kan } \\
\text { (mm Hg) }\end{array}$ & $\begin{array}{l}77.56 \pm 18.77 \\
(60-110)\end{array}$ & $\begin{array}{l}81.81 \pm 58.07 \\
(70-120)\end{array}$ & 0.494 \\
\hline Nabız (I & Jakika) & $\begin{array}{l}80.49 \pm 12.18 \\
(60-120)\end{array}$ & $\begin{array}{l}79.15 \pm 10.77 \\
(56-120)\end{array}$ & 0.292 \\
\hline
\end{tabular}

Tabloda verilen mean \pm SD (min-max) değerlerin karşılaştırılmasında Student T testi kullanıldı. Tabloda verilen \% değerlerin karşılaştırılmasında deskriptif istatistik yöntemi kullanıldı. Kategorik değişkenler için Ki-kare testi $(\chi 2)$ kullanılmıştır. ${ }^{*}$ p $<0.05$ anlamlı olarak kabul edildi.

\section{BULGULAR}

Çalışmada, Ocak 2017-Ocak 2018 tarihleri arasında toplam doğum sayısı 1601 olarak tespit edildi. Bunların 68 (\%4,2)'inin 15-19 yaş adölesan gebe grubunda iken, 168'i $(\% 10,4)$ 20-23 yaş adölesan olmayan gebe grubunda olduğu izlendi. Gebe kadınların yaş dağılımı incelendiğinde; Çalışma grubundaki yaş ortalaması 18.18 \pm 0.98 (15-19) olup, kontrol grubundakilerin ise $21.67 \pm 1.10(20-23)$ olarak bulundu $(\mathrm{P}=0.000)$. İki gruptaki kadınların vücut ağırlığı ortalaması incelendiğinde, adölesan yaş grubunda $67.38 \pm 4.82(56-80) \mathrm{kg}$, adölesan olmayan grupta $70.43 \pm 4.10$ (59-80) kg olarak bulundu ( $\mathrm{P}=0.000)$ (Tablo 1$)$.

Adölesan yaş grubundaki kadınların primipar gebelik oranı \%67,6 iken kontrol grubundaki primipar gebelik oranı \%55,4 olup bulundu $(\mathrm{P}=0.082)$ (Tablo 1). İki gruptaki kadınların yaşayan çocuk sayısı ortalaması incelendiğinde; çalışma grubunda $0.63 \pm 0.86(0-5)$ yll iken, kontrol grubunda ise $0.96 \pm 1.01(0-5)$ yll bulundu $(\mathrm{P}=0.014)$. İki gruptaki kadınların gestasyonel yaş ortalaması incelendiğinde, adölesan yaş grubunda 34.46 44.09 (19-39) hafta, adölesan olmayan grupta $36.47 \pm 2.93$ (23-41) hafta bulundu ( $\mathrm{P}=0.000)$. Hemoglobin değeri ortalaması incelendiğinde; çalışma grubunda $10.55 \pm 2.32(6-16) \mathrm{g} / \mathrm{dl}$, kontrol grubunda $11.50 \pm 1.89$ (9.6-15.92) g/dl bulundu $(\mathrm{P}=0.003)$. Bunların yanı sıra diğer biyokimyasal parametrelerde glukoz, ALT, AST ve idrardaki protein miktarı açısından incelendiğinde iki grup arasındaki fark anlamlı bulundu ( $\mathrm{P}$ değerleri sirasiyla; $\mathrm{P}=0.008$, $\mathrm{P}=0.032, \mathrm{P}=0.003, \mathrm{P}=0.001$ ) (Tablo 2).

İki gruptaki kadınların obstetrik komplikasyonlar gelişme açısından incelendiğinde; adölesan gebelerin \%38,2'sinde preterm eylem geliştiği, \%23,5'inde maternal kan transfüzyonu yapıldığı, \%13,2'sinde maternal yoğun bakım ihtiyacı olduğu ve \%8,8'inde de preeklampsi geliștiği saptandı. Preterm eylem, maternal kan transfüzyonu ve maternal yoğun bakım açısından iki grup arasında istatistiksel fark bulundu ( $\mathrm{P}$ değerleri sirasiyla; $\mathrm{P}=0.000, \mathrm{P}=0.000, \mathrm{P}=0.000$ ) (Tablo 3). Ancak iki grup arasında preeklampsi yönünden fark bulunmadı ( $\mathrm{P}=0.097)$. İki grup sezaryene endikasyonları açısından karşılaştırıldığında; adölesan gebelerin \%10,3'ünün plasenta previa, \%8,8'inde mükerrer sezaryen saptanırken, adölesan olmayan grupta \%3'ünün plasenta previa, \%31,5'inde mükerrer sezaryen bulundu ( $\mathrm{P}$ değerleri sirasıyla; $\mathrm{P}=0.020$, $\mathrm{P}=0.000$ )(Tablo 4). İki grubun yenidoğanları ağırlı yönünden karşılaştırıldığında; çalışma grubunda 
2525.29 \pm 840.04 (200-400) g, kontrol grubunda ise 2836.25 $\pm 716.04 \quad(500-448)$ g bulundu $(\mathrm{P}=0.014)$. İki grubun yanidoğanları 1 . ve 5 . dakika APGAR skoru yönünden karşılaştırıldığında sırasıyla; 1. dakika APGAR skoru çalışma grubunda 5.97 $\pm 2.37 \quad(0-8)$, kontrol grubunda $6.36 \pm 2.02(0-9)$, 5. dakika APGAR skoru çalışma grubunda 7.53 \pm 2.84 (010), kontrol grubunda 8.05 \pm 2.47 (0-10) olarak saptandı ( $\mathrm{P}=0.341, \mathrm{P}=0.191)$ (Tablo5). İki grup amniyon sıvıda mekonyum açısından incelendiğinde; çalışma grubunda \%19,1, kontrol grubunda ise \%8,3'ünde amniyon sivisı mekonyumlu bulundu $(\mathrm{P}=0.018)$. İki gruptaki kadınların hipertansif hastalıklar ve preeklampsi açısından incelendiginde; adölesan grubundaki kadınların \%8,8'inde preeklampsi, kontrol grubundaki kadınların \%3,6'sında preeklampsi bulundu (P=P:0.097) (Tablo3).

Tablo 2: Adölesan gebeler ile kontrol grubu gebelerin doğum esnasındaki biyokimyasal parametrelerinin dağılımı

\begin{tabular}{|l|l|l|c|}
\hline & $\begin{array}{l}\text { Adölesan gebeler } \\
\text { mean } \pm \text { SD(min-max), } \\
\text { n(\%) }\end{array}$ & $\begin{array}{l}\text { Kontrol grubu } \\
\text { gebeler } \\
\text { mean } \pm \text { SD (min- } \\
\text { max), } \\
\text { n(\%) }\end{array}$ & P \\
\hline Hb (g/dl) & $\begin{array}{l}10.55 \pm 2.32 \\
(6.00-16.00)\end{array}$ & $\begin{array}{l}11.50 \pm 1.89 \\
(9.6-15.92)\end{array}$ & $\mathbf{0 . 0 0 3}^{*}$ \\
\hline Htc (\%) & $\begin{array}{l}33.39 \pm 6.04 \\
(11.36-47.00)\end{array}$ & $\begin{array}{l}36.17 \pm 4.49 \\
(22.78-49.21)\end{array}$ & $\mathbf{0 . 0 0 0}^{*}$ \\
\hline Plt (K/uL) & $\begin{array}{l}224.33 \pm 75.69 \\
(71.13-452.00)\end{array}$ & $\begin{array}{l}229.27 \pm 61.84 \\
(96.88-556.30)\end{array}$ & 0.516 \\
\hline $\begin{array}{l}\text { Glukoz } \\
\text { (mg/dL) }\end{array}$ & $\begin{array}{l}90.18 \pm 14.07 \\
(63.00-158.00)\end{array}$ & $\begin{array}{l}85,78 \pm 14,44 \\
(56.00-194.00)\end{array}$ & $\mathbf{0 . 0 0 8}^{*}$ \\
\hline ALT (u/L) & $\begin{array}{l}17.16 \pm 30.83 \\
(2.00-257.00)\end{array}$ & $\begin{array}{l}11.80 \pm 7.43 \\
(3.00-47.00)\end{array}$ & $\mathbf{0 . 0 3 2}^{*}$ \\
\hline AST (u/L) & $\begin{array}{l}19.01 \pm 33.92 \\
(4.00-288.00)\end{array}$ & $\begin{array}{l}13.08 \pm 10.41 \\
(3.00-88.00)\end{array}$ & $\mathbf{0 . 0 0 3}^{*}$ \\
\hline $\begin{array}{l}\text { TiT (Protein) } \\
\text { (mg) }\end{array}$ & $\begin{array}{l}2.01 \pm 22.54 \\
(0.00-80.90)\end{array}$ & $\begin{array}{l}2.28 \pm 11.69 \\
(0.00-64.50)\end{array}$ & $\mathbf{0 . 0 0 1}^{*}$ \\
\hline
\end{tabular}

Kisaltmalar: Hb: Hemoglobin, Htc: Hematokrit, TíT: Tam İdrar Tetkiki, Plt: Platelet, AST: Aspartat aminotransferaz, ALT: Alanin aminotransferaz

Tabloda verilen mean \pm SD (min-max) değerlerin karşılaștırılmasında Student $\mathrm{T}$ testi kullanıldı. Tabloda verilen \% değerlerin karşılaştırılmasında deskriptif istatistik yöntemi kullanıldı. Kategorik değişkenler için Ki-kare testi $(\chi 2)$ kullanılmıştır. *p<0.05 anlamlı olarak kabul edildi.
Tablo 3: Adölesan gebeler ile kontrol grubu gebelerin maternal sonuçlarının dağılımı

\begin{tabular}{|c|c|c|c|c|}
\hline & & \begin{tabular}{|l|} 
Adölesan \\
gebeler \\
n(\%)
\end{tabular} & \begin{tabular}{|l|} 
Kontrol grubu \\
gebeler \\
n(\%)
\end{tabular} & $\mathrm{P}$ \\
\hline \multirow{2}{*}{$\begin{array}{l}\text { Preterm Doğum } \\
\text { Eylemi }\end{array}$} & Yok & $42(\% 61,8)$ & $153(\% 91,1)$ & \multirow[b]{2}{*}{$0.000^{* *}$} \\
\hline & Var & $26(\% 38,2)$ & $15(\% 8,9)$ & \\
\hline \multirow{2}{*}{ Preeklampsi } & Yok & $62(\% 91,2)$ & $162(\% 96,4)$ & \multirow[b]{2}{*}{0.097} \\
\hline & Var & $6(\% 8,8)$ & $6(3,6)$ & \\
\hline $\begin{array}{l}\text { Normal doğum } \\
\text { komplikasyonu }\end{array}$ & Yok & $68(\% 100,0)$ & $168(\% 100,0)$ & \\
\hline $\begin{array}{l}\text { Sezaryen } \\
\text { komplikasyonu }\end{array}$ & Yok & $68(\% 100,0)$ & $168(\% 100,0)$ & \\
\hline \multirow{2}{*}{$\begin{array}{l}\text { Kan transfüzyonu } \\
\text { ihtiyacl }\end{array}$} & Yok & $52(\% 76,5)$ & $164(\% 97,6)$ & \multirow[b]{2}{*}{$0.000 *$} \\
\hline & Var & $16(\% 23,5)$ & $4(\% 2,4)$ & \\
\hline \multirow{2}{*}{$\begin{array}{l}\text { Yoğun bakım } \\
\text { İhtiyacı }\end{array}$} & Yok & $59(\% 86,8)$ & $166(\% 98,8)$ & \multirow[b]{2}{*}{$0.000^{*}$} \\
\hline & Var & $9(\% 13,2)$ & $2(\% 1,2)$ & \\
\hline Maternal Ölüm & Yok & $68(\% 100,0)$ & $168(\% 100,0)$ & \\
\hline
\end{tabular}

Tabloda verilen \% değerlerin karşılaştırılmasında deskriptif istatistik yöntemi kullanıldı.Kategorik değişkenler için Ki-kare testi $(\chi 2)$ kullanılmıștır. ${ }^{*} \mathrm{p}<0.05$ anlamlı olarak kabul edildi.

\section{TARTIŞMA}

Çalışmamızda, Türkiye İstatistik Kurumuna göre Türkiye'de toplam doğurganlık hızının en yüksek il olan Şanlıurfa'da adölesan gebelerin maternal ve fetal sonuçlarını kontrol grubu gebelerle karşılaştırdık. Adölesan dönem somatik, endokrinolojik ve psikolojik gelişim ile karakterize bir dönemdir. Menarşla beraber doğurganlık kazanan adölesan bireyler, gebelik ve ilișkili tüm komplikasyonlar açısından risk altındadırlar. Hem gelişmekte olan ülkeler hem de gelişmiş ülkelerde adölesan gebelikler önemli bir sağlık sorunu olarak ön plana çlkmaktadır6. 
Tablo 4: Sezaryen doğum endikasyonlarının dağılımı

\begin{tabular}{|l|l|l|c|}
\hline & $\begin{array}{l}\text { Adölesan gebel } \\
\text { n(\%) }\end{array}$ & $\begin{array}{l}\text { Kontrol grubu } \\
\text { gebeler } \\
\text { n(\%) }\end{array}$ & $\mathrm{P}$ \\
\hline $\begin{array}{l}\text { İlerlemeyen Doğum } \\
\text { Eylem }\end{array}$ & $1(\% 1,5)$ & $4(\% 2,4)$ & 0.662 \\
\hline Fetal Distres & $9(\% 13,2)$ & $14(\% 8,3)$ & 0.250 \\
\hline $\begin{array}{l}\text { Sefalopelvik } \\
\text { uyumsuzluk }\end{array}$ & $1(\% 1,5)$ & $4(\% 2,4)$ & 0.66 \\
\hline Malprezentasyon & $5(\% 26,3)$ & $14(\% 8,3)$ & 0.803 \\
\hline Mükerrer Sezaryen & $6(\% 8,8)$ & $53(\% 31,5)$ & $\mathbf{0 . 0 0 0}$ \\
\hline $\begin{array}{l}\text { Fetal Anomali } \\
\text { (Hidrosefali, } \\
\text { omfalosel, vb.) }\end{array}$ & $1(\% 1,5)$ & $2(\% 1,2)$ & 0.863 \\
\hline Plasenta previa & $7(\% 10,3)$ & $5(\% 3,0)$ & $\mathbf{0 . 0 2 0}$ \\
\hline Kalp Hastalığı & $0(\% 0,0)$ & $2(\% 1,2)$ & 1.000 \\
\hline Diğer & $4(\% 5,9)$ & $9(\% 5,4)$ & 0.873 \\
\hline
\end{tabular}

Tabloda verilen \% değerlerin karşılaştırılmasında deskriptif istatistik yöntemi kullanıldı.Kategorik değișkenler için Ki-kare testi ( $\chi 2$ ) kullanılmıștır. * ${ }^{*}<0.05$ anlamlı olarak kabul edildi

Türkiye İstatistik Kurumu, adölesan gebelerin doğurganlık hızını, 15-19 yaş grubunda bin kadın başına düşen ortalama canlı doğan çocuk sayısı olarak tanımlamaktadır. Türkiye'de adölesan doğurganlık hızı, 2011 yılında binde 32 iken 2016 yılında binde 24'e düşmüştür. Türkiye'de Diyarbakır ilinde, Ağaçayak ve arkadaşlarının $^{8}$ yaptığı çalışmada adölesan gebe insidansı \%3,6 olarak rapor edilmiştir. Bizim çalışmamızda ise adölesan gebe insidansı $\% 4,2$ olarak tespit edildi.

Çalışmamızda adölesan gebeler ile kontrol gurubu gebelerin maternal ve fetal sonuçlarının karşılaştırılmasında; adölesan gebelerde artmış maternal anemi ve kan transfüzyon ihtiyacl, preterm eylem, yoğun bakım ihtiyacı, düşük doğum ağırlıklı yeni doğan ve amniyon sıvıda mekonyum bakımından adölesan gebelerin riskli olduğu tespit edildi. Çalışmamızda, adölesan gebelerde vajinal doğum ve sezaryen doğumda komplikasyonu saptanmamıștır, ancak adölesan grupta maternal kan transfüzyon ihtiyacl $\% 23,5$, yoğun bakım ihtiyacı \%13,2 olarak bulunmuștur. Bu kadar yüksek oranların etiyolojisinde hastaların çoğu düşük sosyoekonomik ve eğitim düzeyine sahip olduğu için antenatal takipleri düzenli yapılmamış, çoğuna demir preparatları başlanmamış ve beslenmeleri yetersiz olduğundan dolayı anemi açısından artmış demir ihtiyaçları nedeniyle yüksek risk grubunu oluşturmaktadırlar.

Tablo 5: Adölesan gebeler ile kontrol grubu gebelerin fetal sonuçlarının dağılımı

\begin{tabular}{|c|c|c|c|c|}
\hline & \multicolumn{2}{|c|}{$\begin{array}{l}\text { Adölesan gebeler } \\
\text { mean } \pm \text { SD }(\min -\max ) \\
\text { n(\%) }\end{array}$} & \begin{tabular}{|l|} 
Kontrol grubu \\
gebeler \\
mean \pm SD \\
$($ min-max $)$ \\
n(\%)
\end{tabular} & $\mathrm{P}$ \\
\hline $\begin{array}{l}\text { Yeni doğan } \\
\text { bebeğin ağırlığı } \\
\text { (gram) }\end{array}$ & \multicolumn{2}{|c|}{$\begin{array}{l}2525.29 \pm 840.04 \\
(200.00-4000.00)\end{array}$} & $\begin{array}{l}2836.25 \pm 716.04 \\
(500.00-448.00)\end{array}$ & $0.014 *$ \\
\hline 1.dakika APGAR & \multicolumn{2}{|c|}{$\begin{array}{l}5.97 \pm 2.37 \\
(0.00-8.00)\end{array}$} & \begin{tabular}{|l|}
$6.36 \pm 2.02$ \\
$(0.00-9.00)$ \\
\end{tabular} & 0.341 \\
\hline 5.dakika APGAR & \multicolumn{2}{|c|}{$\begin{array}{l}7.53 \pm 2.84 \\
(0.00-10.0)\end{array}$} & $\begin{array}{l}8.05 \pm 2.47 \\
(0.00-10.00)\end{array}$ & 0.191 \\
\hline \multirow{2}{*}{$\begin{array}{l}\text { Amnion mayide } \\
\text { Mekonyum }\end{array}$} & Yok & $55(\% 80,9)$ & $154(\% 91,7)$ & \multirow{2}{*}{ 0.018* } \\
\hline & Var & $13(\% 19,1)$ & $14(\% 8,3)$ & \\
\hline \multirow{2}{*}{ Fetal anomali } & Yok & $66(\% 97,1)$ & $166(\% 71,6)$ & \multirow[b]{2}{*}{0.345} \\
\hline & Var & $2(\% 2,9)$ & $2(\% 1,2)$ & \\
\hline
\end{tabular}

Adölesan dönem gebelikte aneminin var olması; erken doğum tehdidi, düşük doğum ağırlıklı bebek doğurma gibi olumsuz perinatal sonuçların yanı sıra, maternal mortalite ve morbidite artışına da yol açabilir. Çalışmamızda, adölesan gurubundaki hastaların anemi sıklığı kontrol gurubu ile karşılaştırıldığında, literatürde yayınlanan çalışmalarla uygun bulundu ve bu sıklığın adölesan gurubundaki hastalarda daha yüksek olduğu tespit edildi9,10. Adölesan dönemde hemoglobin değerinin çok düşük olması, hızlı büyüme ve gelișmenin devam etmesi, ayrıca gebeliğin getirdiği yük ve bu gebelerin daha fazla nütrisyonel desteğe ihtiyaç duymasıyla açıklanabilir.

Demirgöz ve arkadaşlarının çalışmasında adölesan gebelikler ile adölesan olmayan 
gebelikler karşılaştırılmış ve adölesan gebelikler riskli gebelikler olarak kabul edilmiştir. Çalışmalarında adölesan gebeliklerde erken doğum, müdahaleli doğum, preeklampsi ve maternal anemi riskinin yüksek olduğu rapor edilmiştiri11. Debras ve arkadaşlarının çalışmasında, preterm doğum eylemi oranı adölesan olmayan gruba göre belirgin olarak daha yüksek olduğu rapor edilmiștir ${ }^{12}$. Adölesan gebelerde, preterm doğum eylemi başlatan mekanizma kesin bilinmemekle birlikte, bu durumun, immatur uterus, prostoglandin salınımını arttırarak ortaya çıkan plasental oluşum defektinden kaynaklandığını ileri süren çalışmalar mevcuttur ${ }^{13}$. Bizim çalışmamızda, adölesan gebeler ile kontrol gurubu gebelerin maternal ve fetal sonuçlarının karşılaştırılmasında preterm doğum eylemi bakımından istatistiksel olarak anlamlı fark bulunmuştur $(\mathrm{P}=0.000)$. Medhi ve arkadaşlarının çalışmasında adölesan gebelerde preeklampsi gelişme riski daha yüksek bulunmuştur ${ }^{14}$. Minjares-Granillo ve arkadaşlarının kesitsel çalışmasında ise adölesan gebelerin preeklampsi riski istatistiksel olarak anlamlı bulunmamıştır ${ }^{15}$. Bizim çalışmamızda ise literatürdeki bazı çalışmalarla benzer şekilde, adölesan ve adölesan olmayan gebeler preeklampsi açısından karşılaştırıldığında, istatistiksel olarak anlamlı fark bulunmadı $(\mathrm{P}=0.097)$. Hutcheon ve arkadaşlarının çalışmasında ise preeklampsi görülme sıklığındaki farklılıkların popülasyondaki primipar gebelerin oranı ve maternal yaș dağılımına bağlı olarak değiștiği ileri sürülmüştür ${ }^{16}$.

Literatürde, adölesen gebeler ile adölesan olmayan gebelerin doğum şekli incelendiğinde; adölesanların vajinal doğum oranı yüksek bulunmuştur. Taner ve arkadaşlarının çalışmasında toplam 704 hastadan adölesan yaş gurubundaki hastaların sezaryen oranı $\% 30,7$ iken, üreme çağındaki yaş grubunun $\% 60,4$ oranında sezaryen ile doğumun tercih edildiği rapor edilmiştir ${ }^{17}$. Çalışmamızda, adölesan gebelerin \%44,1'i ve adolesan olmayan gebelerin \%34,5'inde vajinal doğum tercih edilmiştir $(\mathrm{P}=0.227)$. Adölesan gebelerin sezaryen ile doğum oranı \%51,5 iken, kontrol grubu hastaların ise sezaryen ile doğum oranı \%63,1 olarak bulunmuştur ve gruplar arasında anlamlı fark olmadığı belirlenmiştir ( $\mathrm{P}=0.227)$. Çalışmamızda, adölesan gebeler ile kontrol grubu gebelerin normal doğum, sezaryen ve operatif doğum verilerinin karşılaştırılmasında, istatistiksel olarak anlamlı fark olmadığ saptanmıștır. Çalışmamızda, sezaryene alınan adölesan gebeler ile kontrol grubu gebelerin sezaryen endikasyonları incelendiğinde, mükerrer sezaryen ve plasenta previa açısından istatistiksel bakımından anlamlı fark tespit edilmiştir ( $p$ değerleri sırasıyla, $\mathrm{P}=0.000$, $\mathrm{P}=0.020$ ). Fakat, sezaryena alınan adölesan gebeler ile kontrol gurubu gebelerin sezaryen endikasyonları incelendiğinde; CPD, ilerlemeyen doğum eylemi, fetal distres, malprezentasyon, fetal anomali (Hidrosefali, omfalosel, vb.), kalp hastalı̆̆ 1 ve diğerler hastalıklar açısından istatistiksel bakımından fark tespit edilmemiştir $(\mathrm{P}>0.05)$. WHO tarafında yapılan bir çalışmada, perinatal morbidite ve mortalitenin adölesan olan gebelerde daha yüksek olduğu bildirilmiştir ${ }^{18}$. Çalışmamızda adölesan gebeler ile kontrol grubu gebelerde maternal ve fetal mortalite izlenmedi, ancak daha geniş seri çalışmalarına ihtiyaç olduğu kanaatindeyiz.

\section{SONUÇ}

Adölesan gebeliklerde maternal kan transfüzyonu, yoğun bakım ihtiyacı ve preterm doğum eylemi açısından artmış risk ve kötü perinatal sonuçlara neden olduğundan yüksek riskli gebelikler olarak değerlendirilmelidir. Dolayısıyla adölesan gebeliklerin önlenmesi hedeflenmelidir. Adölesan gebeliklerin antenatal takibi ise yüksek riskli gebelikler grubunda yapılması da olası riskleri azaltabileceği kanaatindeyiz. Toplum sağlığı için gebe sağlığına önem vermemiz ve sağlıklı yenidoğanlar amaçlamamız gerekmektedir. 
Çıkar Çatışması: Yazarlar bu yazının hazırlanması ve yayınlanması hususunda çıar çatışması olmadığını beyan etmişlerdir.

Finansal Destek: Çalışmamız, herhangi bir fondan maddi destek almamıştır.

Declaration of Conflicting Interests: The authors hereby declare that they have no conflict of interest.

Financial Disclosure: No financial support was received

\section{KAYNAKLAR}

1. Yoost JL, Hertweck SP, Barnett SN. The Effect of an Educational Approach to Pregnancy Prevention Among High-Risk Early and Late Adolescents. J Adolesc Health. 2014; 55: 222-7.

2. Jolly MC, Sebire N, Harris J, Robinson S, Regan L. Obstetric risks of pregnancy in women less than 18 years old. Obstet Gynecol. 2000; 96: 962-6.

3. Türkiye Nüfus ve Sağlık Araştırması. Hacettepe Üniversitesi Nüfus Etütleri Enstitüsü. Sağlık Bakanlığı Ana Çocuk Sağlığı ve Aile Planlaması Genel Müdürlüğü, Devlet Planlama Teşkilatı ve Avrupa Birliği, Ankara, 2003.

4. Boran P, Gökçay G, Devecioğlu E, Eren T. Child brides. Marmara Medical Journal. 2013; 26: 58-62.

5. Keskinoglu P, Bilgiç N, Picakciefe M, et al.. Perinatal outcomes and risk factors of Turkish adolescent mothers. J Pediatr Adolesc Gynecol. 2007; 20: 19-24.

6. Chandra-Mouli V, Camacho AV, Michaud PA. WHO guidelines on preventing early pregnancy and poor reproductive outcomes among adolescents in developing countries. J Adolesc Health. 2013; 52: 51722.

7. Melekoğlu R, Evrüke C, Kafadar T, ve ark. adölesan gebeliklerin perinatal sonuçları. Türk Jinekoloji ve Obstetrik Derneği Dergisi, (J Turk Soc Obstet Gynecol). 2013; 10: 213-9.
8. Ağaçayak E, Alan B, Turgut A, ve ark. Adölesan Gebelerin Maternal ve Fetal Sonuçlarının Değerlendirilmesi Evaluation of Maternal and Fetal Outcomes in the Adolescents Pregnancy Dicle Tip Dergisi/Dicle Medical Journal. 2016; 43: 344-50.

9. Thekkekkara T, Veenu J. Teenage pregnancy: a comparative study of the outcome and complications. J Indian Med Assoc. 2009; 107: 34-5,40.

10. de Vienne CM, Creveuil C, Dreyfus M. Does young maternal age increase the risk of adverse obstetric, fetal and neonatal outcomes: a cohort study. Eur J Obstet Gynecol Reprod Biol. 2009; 147: 151-6.

11. Demirgöz M, Canbulat N. Adölescent Pregnancy, Review, Turkiye Klinikleri J Med Sci. 2008; 28: 947-52.

12. Debras E, Revaux A, Bricou A, et al. Obstetric and neonatal outcomes of adolescent pregnancies: a cohort study in a hospital in Seine-Saint-Denis France. Gynecol Obstet Fertil. 2014; 42: 579-84.

13. Mukhopadhyay P, Chaudhuri RN, Paul B. Hospitalbased perinatal outcomes and complications in teenage pregnancy in India. J Health Popul Nutr. 2010; 28: 494-500.

14. Medhi R, Das B, Das A, et al. Adverse obstetrical and perinatal outcome in adolescent mothers associated with first birth: a hospital-based case-control study in a tertiary care hospital in North-East India. Adolesc Health Med Ther. 2016; 7: 37-42.

15. Minjares-Granillo RO, Reza-Lopez SA, CaballeroValdez S, et al. Maternal and perinatal outcomes among adolescents and mature women: a hospital-based study in the North of Mexico. J Pediatr Adolesc Gynecol. 2016; 29: 304-11.

16. Hutcheon JA, Lisonkova S, Joseph KS. Epidemiology of pre-eclampsia and the other hypertensive disorders of pregnancy. Best pract Res Clin Obstet Gynecol. 2011; 25: 391-403.

17. Taner CE, Kırmızı DA, İriş A, Başoğul Ö. Adölesan gebeliklerin sonuçları. Göztepe Tıp Dergisi. 2012; 27: 610.

18. Blomberg M, Birch Tyrberg R, Kjølhede P. Impact of maternal age on obstetric and neonatal outcome with emphasis on primiparous adolescents and older women: a Swedish Medical Birth Register study. BMJ Open. 2014; 4: e005840. 